\section{Summary}

Some controversial aspects of rheumatic heart disease are discussed in the light of personal experience in Edinburgh. Symptoms are not always a reliable guide to severity, and the correct time for surgical treatment should be based on an objective assessment. Dangers of delay include progressive damage to the pulmonary circulation, lungs, right ventricle, and liver, and the risks of systemic embolism, pulmonary oedema, and pulmonary infarction.

The New York Heart Association classification of disability is unreliable and a potentially dangerous guide.

The concepts of the pliant valve, critical stenosis, areas of auscultation, and the ejection murmur are criticized.

No relation has been found between the size of the left auricle or atrium and the incidence of embolism. There is reason to doubt the value of anticoagulants.

In relation to mitral valvotomy factors influencing operative mortality, complications, traumatic mitral incompetence, sys- temic embolism, and restenosis are discussed, and also the influence of calcification and of associated aortic valvular disease.

Reference is also made to the place of open heart surgery.

I am grateful to my colleagues, Andrew Logan, with whom I have been so closely associated since he carried out our first valvotomy in 1950 and later introduced the transventricular approach to the mitral valve and, for many years now, Arthur Kitchin, who as a clinician is also in charge of our laboratory, for innumerable discussions and for their advice on the subject matter of this paper.

\section{REFERENCES}

Donald, K. W., Bishop, J. M., Wade, O. L., and Wormald, P. N. (1957). Clin. Sci., 16, 325 .

Kitchin, A., and Turner, R. (1967). Brit. Heart 7., 29, 137.

Sellors, T. H., Bedford, D. E., and Somerville, W. (1953). Brit. med. F., 2, 1059.

\title{
Folate Status and Requirement in Pregnancy
}

\author{
I. CHANARIN, * M.D., B.SC., D.C.P., M.C.PATH. ; DOREEN ROTHMAN, $\dagger$ B.SC., M.R.C.O.G. \\ AUDREY WARD, $\dagger$ M.B., CH.B., M.R.C.o.G.; JANET PERRY,‡ B.SC.
}

Brit. med. F., 1968, 2, 390-394

A number of notable studies on pregnancy anaemia have appeared in the last few years. In particular the studies by Lowenstein's group in Montreal have clarified many of the uncertainties in this field (deLeeuw et al., 1966 ; Lowenstein et al., 1966a, 1966b). In these, as in almost all studies, evidence of both iron and folate deficiency was common and was associated with a megaloblastic form of haemopoiesis in a high proportion of patients. Thus there is a wide agreement about the desirability of both an iron and a folate supplement in pregnancy so that the physiological need for these is met without undue depletion of maternal stores. These aspects were reviewed in the British Medical fournal (1964). There is a difference of opinion, however, about the amount of folate needed each day in pregnancy, and amounts between 50 and $5,000 \mu \mathrm{g}$. are prescribed.

The purpose of this study was twofold. Firstly, to study the changes in folate status in pregnancy in the absence of associated iron deficiency, and, secondly, under these circumstances to determine the amount of additional folate required to maintain normal tissue stores of folate throughout pregnancy. Iron deficiency was largely eliminated by giving $1 \mathrm{~g}$. of parenteral iron to all subjects in early pregnancy. Folate status was assessed by assay of the red cell (and serum) folate concentration and the state of haemopoiesis by carrying out a marrow aspiration at the end of pregnancy. Folate intake was assessed by direct assay of daily food collection in 16 subjects. Half the women taking part in the study were given an oral daily folate supplement after the 20th week of pregnancy. This paper reports our observations of the effect of the folate supplement, and, secondly, compares the finding in the group of patients who showed megaloblastic haemopoiesis with the finding in the whole group.

- Reader in Haematology, St. Mary's Hospital Medical School, London W.2.

† Lecturer in Obstetrics, St. Mary's Hospital Medical School, London W.2.

$\ddagger$ Technical Officer, M.R.C. Experimental Haematology Research Unit, London $\mathbb{W} .2$.

\section{Patients, Materials, and Methods}

Two hundred and six women attending the antenatal clinic at St. Mary's Hospital took part in the study. All were less than 16 weeks pregnant at the first attendance, and in order to eliminate iron deficiency all received $1 \mathrm{~g}$. of intravenous iron dextran as four $250-\mathrm{mg}$. doses at weekly intervals. At the 20 th week they were allotted to one of two groups, receiving taolets dispensed in a bottle with a grey or a red label. These were to be taken once daily, and contained either ferrous fumarate $260 \mathrm{mg}$. or ferrous fumarate $260 \mathrm{mg}$. and $100 \mu \mathrm{g}$. of folic acid, the survey being conducted as a blind trial.

On the first attendance (average 15 weeks) blood was taken for a blood count, serum iron estimation, and folate determination of both serum and red cells. This was repeated at the 30 th and 38th weeks of pregnancy and a sternal marrow aspiration was performed in the 37 th-38th week. All the marrows were assessed at the end of the survey without any knowledge of the colour of tablet taken or of any of the assay results obtained.

Haematological methods were those set out by Dacie and Lewis (1963). Neutrophil polymorphs having five or more distinct nuclear segments were termed hypersegmented, the normal frequency of such cells being 0 to $3 \%$. Marrows were regarded as showing megaloblastic haemopoiesis when megaloblastic change was present in erythroblasts. Giant metamyelocytes were usually present as well. Iron status was assessed by both serum iron estimation and staining of marrow spreads for iron by Perls's Prussian-blue method.

Red cell and serum folates were determined by microbiological assay with the method of Toepfer et al. (1951) and Lactobacillus casei as the test organism. One gramme of ascorbate was added to each $500 \mathrm{ml}$. of medium. For red cell folate assay the blood was diluted tenfold in a $0.1 \mathrm{M}$ phosphate-ascorbate buffer pH 6 (Hansen, 1964). In our hands this method gave red cell folate results one-third lower than that obtained when blood was diluted in an aqueous solution of ascorbate. How- 
ever, as we were concerned primarily with changes in red cell folate, dilution of whole blood in buffer was used throughout this study. The normal range with this method is 80 to 245 $\mathrm{m} \mu \mathrm{g}$. $/ \mathrm{ml}$. with a mean of $165 \mathrm{~m} \mu \mathrm{g} . / \mathrm{ml}$. packed red cells. The range for serum folate in healthy subjects is 5 to $20 \mathrm{~m} \mu \mathrm{g} . / \mathrm{ml}$.

Methods for the assay of food folate are described elsewhere (Chanarin et al., 1968).

\section{A. Folate Requirement in Pregnancy}

\section{Results}

Dietary Folate Intake.-The folate content of 111 separate 24-hour food collections assayed with $L$. casei before and after incubation with pancreatic enzymes was $160 \mu \mathrm{g}$. of free folate (range 53 to $296 \mu \mathrm{g}$.) and $676 \mu \mathrm{g}$. of total folate (range 198 to $1,615 \mu \mathrm{g}$.). These results are reported in detail elsewhere (Chanarin et al., 1968). There was a significant correlation between the dietary folate intake and the red cell folate level $(\mathbf{r}=0.81 ; \mathrm{P}=0.001)$.

Effect of a Folate Supplement (Table I).-There were no significant differences between the two groups of women at about the 15 th week of pregnancy.

(1) Effect on Red Cell Mass.-Though both haemoglobin and P.C.V. were slightly higher in the group receiving folate the differences were probably not significant $(P=0.05$ for haemoglobins and 0.1 for P.C.V.).

(2) Effect on Blood Film.-No abnormalities were noted in the appearance of the red cells in any of the women, including those subsequently noted to have megaloblastic changes in the marrow. Neutrophil lobe counts showed that at the 37 th week $6 \%$ of patients not given folate had hypersegmented neutrophils whereas this was so in $1 \%$ of those receiving folate.

(3) Folate Status.-There was no significant difference in serum or red cell folate levels at the 15 th week. Thereafter the difference between the two groups was highly significant $(P=0.001)$. The red cell folate continued to decline in those not receiving folate. In those taking $100 \mu \mathrm{g}$. of folate daily there was a rise in the red cell folate, which was thereafter maintained in the last quarter of pregnancy (Fig. 1).

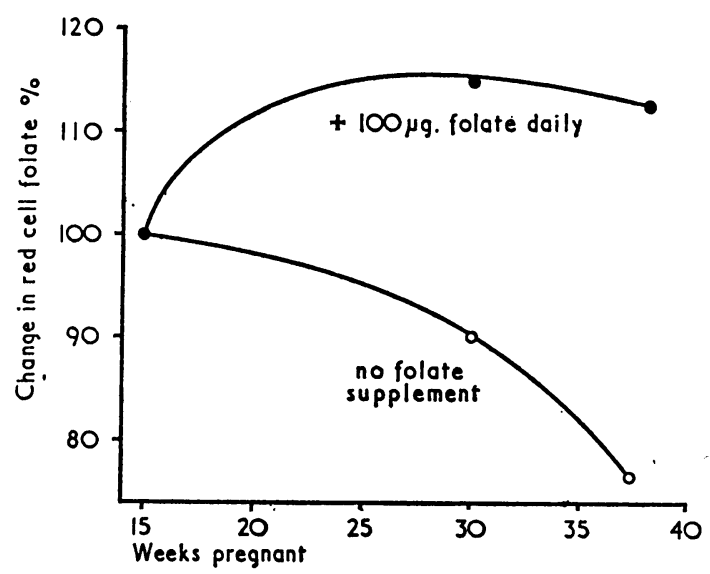

FIG. 1.- Change in red cell folate concentration in pregnant women receiving iron only and iron with $100 \mu \mathrm{g}$. of folate daily after the 20 th week of pregnancy.
(4) Marrow Change.-Only 3 out of 201 patients from whom satisfactory marrow samples were obtained did not have demonstrable iron in the marrow at 37 weeks. Megaloblastic change in both erythroid and myeloid cells were present in 13 out of 100 women not receiving folate and in 5 out of 101 receiving folate.

\section{Discussion}

An adequate folate supplement in pregnancy should both maintain tissue stores of folate and maintain normoblastic haemopoiesis. In this study, as in others, the folate supplement, though adequate in maintaining serum and red cell folate levels and adequate in eliminating megaloblastic anaemia as a clinical entity, failed to prevent abnormal marrow changes in $5 \%$ of patients. Larger folate supplements have been equally unsuccessful in this respect, and these range from $15 \mathrm{mg}$. $(15,000$ $\mu \mathrm{g}$.) given weekly or fortnightly (Dawson et al., 1962) to 500 $\mu \mathrm{g}$. daily used by Lowenstein et al. (1966a). In many of these women failure to take their tablets is the probable explanation, but where this is not the case then the explanation is not understood at the present time.

This study has shown that the folate requirements in pregnancy are met by a free folate intake of $260 \mu \mathrm{g}$./day and a total folate intake (including polyglutamates) of $776 \mu \mathrm{g} . /$ daythat is, a supplement of $100 \mu \mathrm{g}$. of pteroylglutamic acid daily while taking a normal diet.

This is in agreement with the observations of Hansen and Rybo (1967), who found that the mean whole blood folate fell with an oral folate supplement of $50 \mu \mathrm{g}$., increased slightly with $100 \mu \mathrm{g}$., and showed a considerable increase with 200 and 500 $\mu \mathrm{g}$. of folate given daily. The same pattern of results was noted when the serum folate levels were measured. On the other hand, Willoughby (1967) found that there was no change in whole blood folate levels on a $100-\mu \mathrm{g}$. folate supplement. Indeed, the levels were lower than in patients not given any supplement at all. The explanation for these discrepant observations is not clear.

\section{B. Comparison of Normoblastic and Megaloblastic Groups}

\section{Haematology}

There were no differences in the mean haemoglobin and haematocrit values in the three groups of patients (Table I)namely, (a) all those receiving iron and folate (105), (b) all those receiving only iron (101), and (c) those found to show megaloblastic changes (18).

The distribution of haemoglobin values (Fig. 2) is of particular interest because iron deficiency had been eliminated and stainable iron was present in the marrow in the last weeks of pregnancy in all but three women. The relatively low haemoglobin values (10 to 11 g.) in 31 women $(15 \%)$ at the 30th week is thus due to haemodilution and not to lack of iron. Haemoglobin values in the megaloblastic group were the same as in the whole group. On this basis the lower limit of haemoglobin concentration in the latter half of pregnancy is $10 \mathrm{~g} . / 100 \mathrm{ml}$.

TABLE I.-Changes in Various Values Throughout Pregnancy

\begin{tabular}{|c|c|c|c|c|c|c|c|c|c|c|}
\hline & & \multicolumn{6}{|c|}{ All Pregnant Subjects (206) } & \multirow{2}{*}{\multicolumn{3}{|c|}{ Megaloblastic Group Only (18) }} \\
\hline & & \multicolumn{3}{|c|}{ Folate Supplement (105) } & \multicolumn{3}{|c|}{ No Supplement (101) } & & & \\
\hline & & $\pm 15 \mathrm{w}$. & $30 \mathrm{w}$. & 38 w. & $\pm 15 \mathrm{w}$. & $30 \mathrm{w}$. & $38 \mathrm{w}$. & $\pm 15 \mathrm{w}$. & $30 \mathrm{w.}$ & $38 \mathrm{w}$. \\
\hline 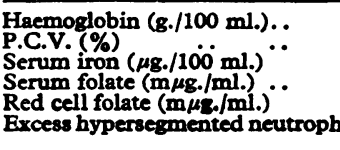 & $\begin{array}{ll}\because & \because \\
\because & \because \\
\ddot{\text { hils }}(\%) & \because .\end{array}$ & $\begin{array}{r}12 \cdot 5 \\
38 \cdot 0 \\
122 \cdot 0 \\
6 \cdot 6 \\
165 \cdot 0 \\
1\end{array}$ & $\begin{array}{r}12 \cdot 0 \\
36 \cdot 0 \\
102 \cdot 0 \\
6 \cdot 7 \\
190 \cdot 0 \\
0\end{array}$ & $\begin{array}{r}12 \cdot 8 \\
39 \cdot 0 \\
110 \cdot 0 \\
6 \cdot 3 \\
187 \cdot 0 \\
1\end{array}$ & $\begin{array}{r}12 \cdot 2 \\
37 \cdot 0 \\
114 \cdot 0 \\
6 \cdot 1 \\
157 \cdot 0 \\
5\end{array}$ & $\begin{array}{r}12 \cdot 0 \\
36 \cdot 0 \\
101 \cdot 0 \\
4 \cdot 5 \\
139 \cdot 0 \\
3\end{array}$ & $\begin{array}{r}12 \cdot 5 \\
38 \cdot 0 \\
109 \cdot 0 \\
4 \cdot 2 \\
118 \cdot 0 \\
6\end{array}$ & $\begin{array}{r}12 \cdot 3 \\
38 \cdot 0 \\
104 \cdot 0 \\
5 \cdot 4 \\
131 \cdot 0 \\
0\end{array}$ & $\begin{array}{r}12 \cdot 0 \\
36 \cdot 0 \\
96 \cdot 0 \\
4 \cdot 2 \\
129 \cdot 0 \\
6\end{array}$ & $\begin{array}{r}13 \cdot 0 \\
39 \cdot 0 \\
110 \cdot 0 \\
3 \cdot 9 \\
89 \cdot 0 \\
17\end{array}$ \\
\hline
\end{tabular}


Eighteen out of 201 marrows examined showed megaloblastic haemopoiesis. Five of these women had received iron and folate and 13 only iron. Seven women in the survey had an increase in hypersegmented neutrophils in blood films. These cells were between 3 and $5.5 \%$ of the total neutrophils and all but one of these women had been given the iron supplement alone. Only three of these women had megaloblastic marrow changes. The neutrophils appeared normal in the other 15 women with megaloblastic marrow changes.
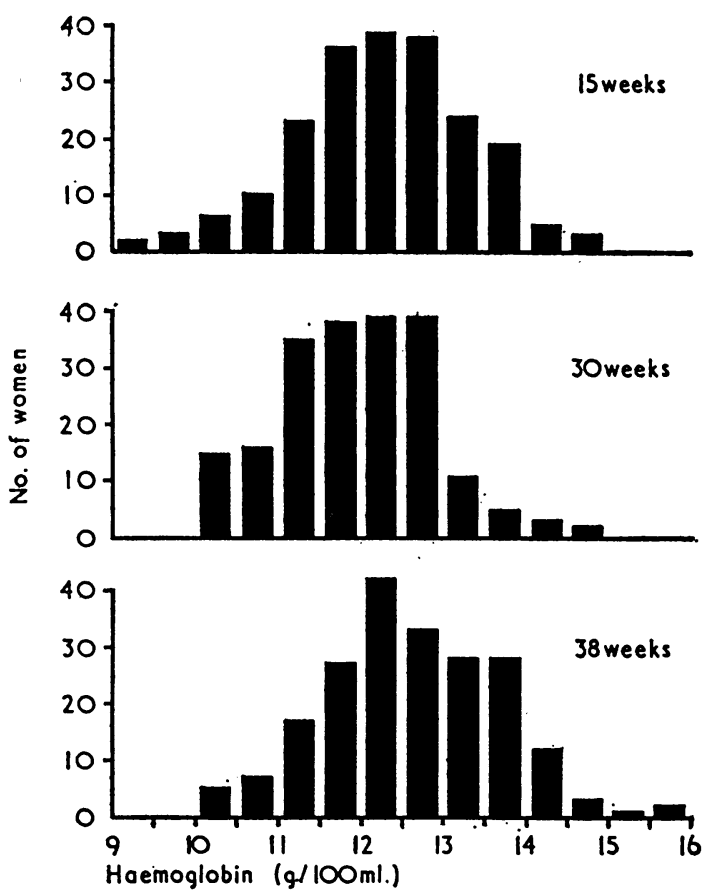

Fig. 2.-Haemoglobin values in 105 normal women with adequate iron stores and receiving a folate supplement in pregnancy.

Combining the data we reported in a previous study (Chanarin et al., 1965b), the frequency of hypersegmented neutrophils in relation to iron and folate therapy in pregnancy is shown in Table II.

TABLE II.-Frequency of Hypersegmented Neutrophils in Late Pregnancy

\begin{tabular}{|c|c|c|c|}
\hline Group & & $\begin{array}{c}\text { No. of } \\
\text { Pregnant Women }\end{array}$ & $\begin{array}{l}\text { Hypersegmented } \\
\text { Neutrophils (\%) }\end{array}$ \\
\hline $\begin{array}{l}\text { No supplement } \\
\text { Oral iron } \quad . . \\
\text { Parenteral iron } \\
\text { Parenteral iron and }\end{array}$ & 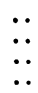 & $\begin{array}{r}30 \\
71 \\
101 \\
105\end{array}$ & $\begin{array}{c}23^{*} \\
6^{*} \\
6^{*} \\
1\end{array}$ \\
\hline
\end{tabular}

- Approximately half these patients had megaloblastic changes in the marrow.

\section{Seasonal Distribution of Megaloblastic Anaemia}

The frequency of marrow aspirations and megaloblastic haemopoiesis in relation to the time of the year is shown in Table III. Megaloblastic haemopoiesis was three times as frequent from January to March as in the latter half of the year. The mean red cell folate levels were lower in those

TABLE III.-Seasonal Distribution of Megaloblastic Haemopoiesis in

\begin{tabular}{|c|c|c|c|c|c|}
\hline \multirow{2}{*}{\multicolumn{3}{|c|}{ Month }} & \multirow{3}{*}{$\begin{array}{c}\begin{array}{c}\text { Na of } \\
\text { Marrow } \\
\text { Aspirations }\end{array} \\
45 \\
46 \\
71 \\
39\end{array}$} & \multicolumn{2}{|c|}{ Megaloblastic } \\
\hline & & & & No. & $\%$ \\
\hline $\begin{array}{l}\text { January-March ... } \\
\text { April-June } \\
\text { July-September... } \\
\text { October-December }\end{array}$ & $\ddot{0}$ & $\begin{array}{l}\ldots \\
\because \\
\cdots\end{array}$ & & $\begin{array}{l}7 \\
5 \\
4 \\
2\end{array}$ & $\begin{array}{r}15.5 \\
10.9 \\
5.6 \\
5.2\end{array}$ \\
\hline Total & . & .. & 201 & 18 & \\
\hline
\end{tabular}

patients reaching term from January to March than in the latter half of the year, but the differences were not significant.

\section{Folate Status}

The decline in the red cell folate concentration from a mean value of $157 \mathrm{~m} \mu \mathrm{g} . / \mathrm{ml}$. at the 15 th week to $139 \mathrm{~m} \mu \mathrm{g}$. at 30 weeks and $118 \mathrm{~m} \mu \mathrm{g}$. at 37-38 weeks is shown in Fig. 3 and Table IV. Ten per cent. of women had red cell folate values below the lower limit of $80 \mathrm{~m} \mu \mathrm{g} . / \mathrm{ml}$. found in non-pregnant controls with this particular technique. There was a significant rise in the red cell folate values in those receiving $100 \mu \mathrm{g}$. of folate daily, and after the 30th week this level was sustained. Only two women given the folate supplement showed a low red cell folate near term, and the steady fall in the red cell folate values in these women suggested that they may not have been taking their tablets.

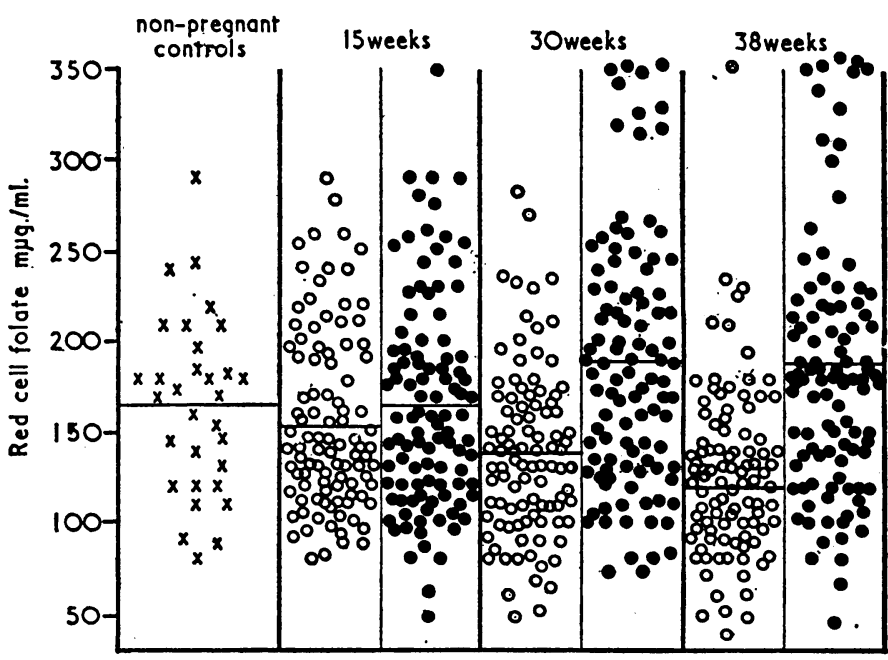

FIg. 3.-Red cell folate values in pregnancy in those receiving $100 \mu g .0$ folate daily $(O)$ and those without a folate supplement $(O)$.

TABLE IV.-Changes in Mean Red Cell Folate in Various Pregnont Groups

\begin{tabular}{|c|c|c|c|c|c|c|}
\hline & \multicolumn{6}{|c|}{ Mean Red Cell Folate* (m $\mu_{\text {g. }} / \mathrm{ml}$.) } \\
\hline & \multirow{2}{*}{ $\pm 15 \mathrm{w}}$. & \multirow{2}{*}{$30 \mathrm{w}}$. & \multirow{2}{*}{$38 \mathrm{w.}$} & \multicolumn{3}{|c|}{$\%$ Below $80 \mathrm{~m} \mu \mathrm{g} . / \mathrm{ml}$. } \\
\hline & & & & $\pm 15 \mathrm{w}$. & $30 \mathrm{w}$. & $38 \mathrm{w}$. \\
\hline $\begin{array}{l}\text { All pregnant subjects: } \\
\text { Folate supplement (105) } \\
\text { No folate supplement (101) } \\
\text { Megaloblastic pregnancy: }\end{array}$ & $\begin{array}{l}165 \\
157\end{array}$ & 190 & 187 & 2 & 2 & 10 \\
\hline $\begin{array}{l}\text { Both groups (18) } \\
\text { Folate supploment }(5) \\
\text { No folate supplement }(13)\end{array}$ & $\begin{array}{l}131 \\
131 \\
132\end{array}$ & $\begin{array}{l}129 \\
147 \\
121\end{array}$ & $\begin{array}{r}89 \\
121 \\
76\end{array}$ & $\begin{array}{l}\mathbf{0} \\
\mathbf{0} \\
\mathbf{0}\end{array}$ & $\begin{array}{r}22 \\
0 \\
31\end{array}$ & $\begin{array}{l}39 \\
20 \\
46\end{array}$ \\
\hline
\end{tabular}

- Red cell folate levels in healthy controls using the method described by Hansen (1964) show a range of 80 to $280 \mathrm{m \mu g}$./ml., mean 165.

The mean red cell folate in all the women at about 15 weeks was $162 \mathrm{~m} \mu \mathrm{g} . / \mathrm{ml}$. and in 18 women who were subsequently found to show megaloblastic features it was $131 \mathrm{~m} \mu \mathrm{g} . / \mathrm{ml}$. This difference is significant $(\mathbf{P}=0.01)$. It indicates that women who become megaloblastic enter pregnancy with suboptimal folate stores. There is little doubt that this arises on a nutritional basis, as there is a highly significant correlation between the red cell folate levels and the dietary folate intake.

The changes in red cell folate in 18 women who were found to be megaloblastic at the 37th-38th week, are shown in Fig. 4 and Table IV. Though the decline in red cell folate is more pronounced than in the whole group, only 7 out of 18 women had red cell folate levels below the lower limit of the nonpregnant range. This is in agreement with the observations of Lowenstein et al. (1966a) and Varadi et al. (1966).

The mean serum folate level in the 18 megaloblastic patients (3.9 $\mathrm{m} \mu \mathrm{g} . / \mathrm{ml}$.) was less than the mean value in the group 
receiving only iron $(4.2 \mathrm{~m} \mu \mathrm{g}$.), and this was possibly significant $(\mathbf{P}=0.05)$. Only four of the megaloblastic group had serum folate levels between 1 and $2 \mathrm{~m} \mu \mathrm{g} . / \mathrm{ml}$., seven had values between 2 and $4 \mathrm{~m} \mu \mathrm{g}$., four had values between 4 and $5 \mathrm{~m} \mu \mathrm{g}$., and one had a serum folate value of $7 \mathrm{~m} \mu \mathrm{g}$.

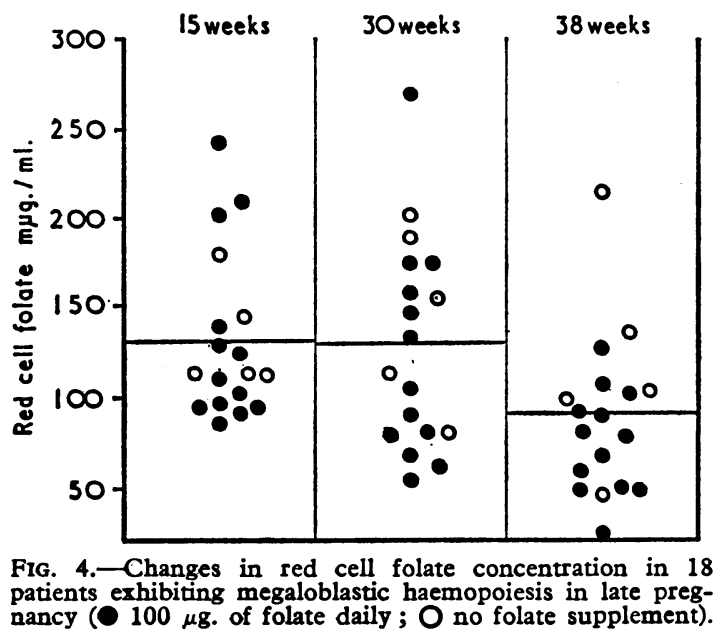

\section{Red Cell Folate Values in Pregnant Women taking Anticonvulsant Drugs}

There is a very rapid decline in red cell folate in pregnancy in treated epileptics. The red cell folate and haemoglobin values in a woman taking diphenylhydantoin during two pregnancies are shown in Fig. 5. In the first pregnancy the red cell folate level fell from $340 \mathrm{~m} \mu \mathrm{g} . / \mathrm{ml}$. to $55 \mathrm{~m} \mu \mathrm{g} . / \mathrm{ml}$. Early in the
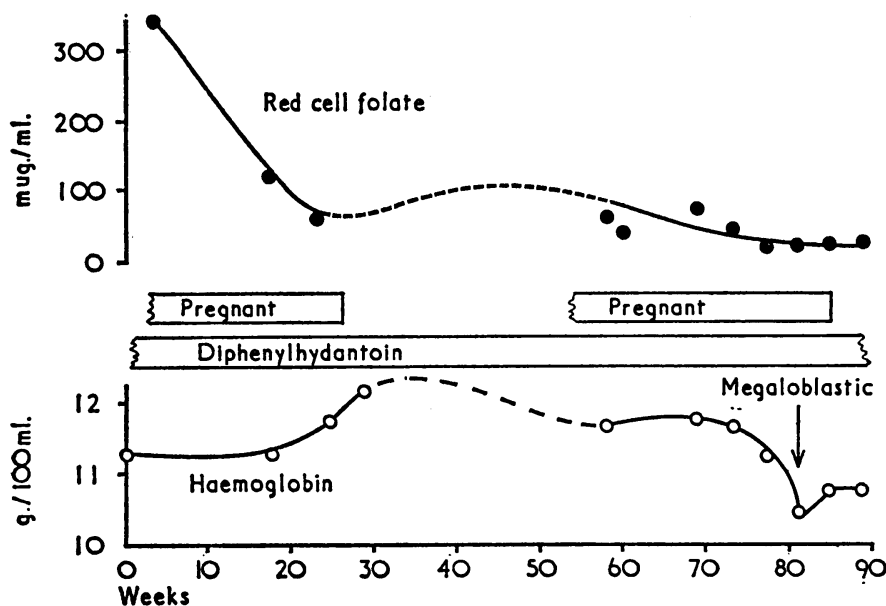

FIG. 5.- Changes in red cell folate and haemoglobin concentration during the first and second pregnancies of a patient with epilepsy taking

second pregnancy the level was $55 \mathrm{~m} \mu \mathrm{g} . / \mathrm{ml}$. and declined to $35 \mathrm{~m} \mu \mathrm{g} . / \mathrm{ml}$. in the last 10 weeks of pregnancy. The peripheral blood film was macrocytic and the marrow showed megaloblastic haemopoiesis. The association between anticonvulsant therapy and megaloblastic anaemia in pregnancy has been noted by Gatenby (1960).

\section{Red Cell Folate Values in Abortion}

Seven women who initially entered the survey had a spontaneous abortion. The mean red cell folate in this group was $157 \mathrm{~m} \mu \mathrm{g} . / \mathrm{ml}$. (114 to $230 \mathrm{~m} \mu \mathrm{g} . / \mathrm{ml}$.) at about the 15 th week of pregnancy as compared with an overall mean of $162 \mathrm{~m} \mu \mathrm{g} . / \mathrm{ml}$. for all the other women in the survey at their initial visit (about the 15 th week). Thus there is no support for the suggestion that folate deficiency is a cause of abortion.

Further there was no correlation between folate status, urinary tract infection, and antepartum haemorrhage.

\section{Red Cell Folate in Relation to Birth Weight}

The mean red cell folate level at 37 weeks in the mothers with infants of less than $2,500 \mathrm{~g}$. $\left(5 \frac{1}{2} \mathrm{lb}\right.$.) was $128 \mathrm{~m} \mu \mathrm{g} . / \mathrm{ml}$. as compared with a mean red cell folate level in excess of $150 \mathrm{~m} \mu \mathrm{g} . / \mathrm{ml}$. in the rest of the group. These differences were not statistically significant. The mean size of the infant in those with megaloblastic haemopoiesis was $3,600 \mathrm{~g}$. (7 lb. $15 \mathrm{oz}$.).

\section{Discussion}

\section{Frequency of Megaloblastic Anaemia in Pregnancy}

None of the subjects in the survey became anaemic and only three showed an increase in hypersegmented neutrophils which indicated a megaloblastic process.

The expected frequency of megaloblastic anaemia in a group of varied social background as this is of the order of 1 to $2 \%$ (Giles and Shuttleworth, 1958), though this figure will be lower in any group with a high proportion of primiparae. On the other hand, early megaloblastic changes in the marrow are found in $25 \%$ of all pregnant women (Beaven et al., 1966 ; Lowenstein et al., 1966b ; Turchetti et al., 1966). In this study $13 \%$ of marrows in those given only iron showed megaloblastic changes, and this was reduced to $5 \%$ in those given a folate supplement as well. A possible explanation for the lower frequency of marrow changes in this study is that all had received adequate amounts of iron in early pregnancy. There is some evidence that iron deficiency is itself a causative factor in producing folate deficiency (Chanarin et al., 1965b). Willoughby (1967) found an overt megaloblastic anaemia in 24 out of 706 women $(3.4 \%)$ given a placebo as compared with 10 out of $736(1.4 \%)$ given oral iron in pregnancy. Similarly in the study reported by Lowenstein et al. (1966b) the megaloblastic group had a higher frequency of associated iron deficiency than subjects who were normoblastic. Their interpretation was that this merely reflected the inadequate nutritional background of these particular patients, but this explanation cannot be sustained in the comparison of the two large groups reported by Willoughby (1967).

\section{Red Cell Folate}

Perhaps the most interesting observation to emerge from this study was that at about the 15 th week of pregnancy the group of women who were found to be megaloblastic in the last weeks of pregnancy had significantly lower red cell folate levels $(131 \mathrm{~m} \mu \mathrm{g} . / \mathrm{ml}$.) as compared with the overall level (162 $\mathrm{m} \mu \mathrm{g} . / \mathrm{ml}$.). The mean red cell folate level in non-pregnant controls with this technique was $165 \mathrm{~m} \mu \mathrm{g} . / \mathrm{ml}$. Further, not only is the red cell folate a useful guide to the body stores of folate but there is a close correlation between the red cell folate and the dietary folate content. This emphasizes that megaloblastic anaemia in pregnancy is basically a nutritional anaemia in which pregnancy produces a temporary increase in requirements for the vitamin and that the nutritional background of the patients is an important factor in determining their ability to cope with added folate stress of pregnancy.

The same conclusion was reached by Temperley et al. (1968), who found that eight out of nine patients with serum folate levels of less than $2 \mathrm{~m} \mu \mathrm{g} . / \mathrm{ml}$. in early pregnancy were megaloblastic before term. The mean serum folate level in early pregnancy in those becoming megaloblastic was 2.0 $\mathrm{m} \mu \mathrm{g} . / \mathrm{ml}$. and in those remaining normoblastic $5.4 \mathrm{~m} \mu \mathrm{g} . / \mathrm{ml}$. 


\section{Seasonal Incidence}

A higher frequency of megaloblastic anaemia in pregnancy towards the end of winter and early spring was noted by Gatenby (1956), Thompson (1957), Forshaw (1957), and Coyle and Geoghegan (1962). Others have not observed this distribution in their cases (Giles and Shuttleworth, 1958 ; MacKenzie and Abbott, 1960 ; Lowestein et al., 1966b). In this study the frequency was three times as high in January to March as in the latter half of the year. As pointed out by others this is probably due to a decline in the availability of dietary folate and lack of fresh vegetables.

\section{Diagnosis of Megaloblastic Haemopoiesis}

It is clear that there are no reliable "diagnostic aids" in the diagnosis of megaloblastic anaemia in pregnancy other than the demonstration of megaloblastic haemopoiesis by marrow aspiration. Red cell folate is abnormally low in only half the patients, and serum folate levels are low in pregnancy irrespective of the state of haemopoiesis. The failure of red cell folate to reflect folate deficiency is due to the relatively slow turnover of red cells. Folate is incorporated at the time of red cell formation, and there is possibly some turnover of folate in reticulocytes, since these have a relatively high folate content, but thereafter folate appears to be locked in the red cell until the end of its life-span. Thus in disorders of recent onset the red cell folate level underestimates the frequency and degree of folate deficiency, and for this reason does not always mirror folate status.

\section{Summary}

The addition of $100 \mu \mathrm{g}$. of folate to a normal diet resulted in elevation of the red cell folate level, which was maintained at the higher level after the 30th week of pregnancy. It is suggested that $100 \mu \mathrm{g}$. of pteroylglutamic acid daily is satisfactory as a folate supplement in pregnancy.

Megaloblastic haemopoiesis was found in $13 \%$ of 105 women given only iron in pregnancy and in $5 \%$ of women given iron and $100 \mu \mathrm{g}$. of folate daily. None were anaemic and only three showed minor changes in peripheral blood films.
Megaloblastic change was three times as frequent during the late winter months as compared with the latter half of the year. The women whose marrows showed megaloblastic features in late pregnancy were found to have significantly lower red cell folate values at the 15 th week of pregnancy as compared with the patients who remained normoblastic, suggesting nutritional folate deficiency as the underlying causative factor.

Women who aborted had the same red cell folate values in early pregnancy as other women in the survey. There was no relation between birth weight and red cell folate levels.

We are indebted to Professor $P$. Huntingford for allowing us to make these observations on patients under his care, to the nursing staff of the antenatal clinics for their help, and to Miss Edith Tripp for considerable technical help. We are indebted to Glaxo Laboratories for providing the tablets and for financial assistance.

REFERENCES

Beaven, G. H., Dixon, G., and White, J. C. (1966). Brit. F. Haemat., 12, 777.

Brit. med. 7., 1964, 2, 1248.

Chanarin, I., Rothman, D., Ardeman, S., and Berry, V. (1965a). Brit. J. Haemat., 11, 557

Chanarin, I., Rothman, D., and Berry, V. (1965b). Brit. med. F., 1, 480

Chanarin, I., Rothman, D., Perry, J., and Stratfull, D. (1968). Brit. med. 7., 2, 394.

Coyle, C., and Geoghegan, F. (1962). Proc. roy. Soc. Med., 55, 764.

Dacie, J. V., and Lewis, S. M. (1963). Practical Haematology, 3rd ed. London.

Dawson, D. W., More, J. R. S., and Aird, D. C. (1962). Lancet, 2, 1015 deLeeuw, N. K. M., Lowenstein, L., and Hsieh, Y.-S. (1966). Medicine (Baltimore), 45, 291.

Forshaw, J. W. B. (1957). Lancet, 1, 1249.

Gatenby, P. B. B. (1956). Proc. Nutr. Soc., 15, 115

Gatenby, P. B. B. (1956). Proc. Nutr. Soc.,

Gatenby, P. B. B. (1960). Lancet, 2, 1004.

Giles, C., and Shuttleworth, E. M. (1958). Lancet, 2, 1341.

Hansen, H. A. (1964). On the Diagnosis of Folic Acid Deficiency. Stockholm

Hansen, H., and Rybo, G. (1967). Acta obstet. gynec. scand., 46, Suppl. No. $7,107$.

Lowenstein, L., Brunton, L., and Hsieh, Y.-S. (1966b). Canad. med. Ass. 7., 94, 636.

Lowenstein, L., Cantlie, G., Ramos, O., and Brunton, L. (1966a) Canad. med. Ass. Ұ., 95, 797.

MacKenzie, A., and Abbott, J. (1960). Brit. med. f., 2, 1114

Temperley, I. J., Meehan, M. J. M., and Gatenby, P. B. B. (1968). Brit. f. Haemat., 14, 13.

Thompson, R. B. (1957). Lancet, 1, 1171

Toepfer, E. W., Zook, E. G., Orr, M. L., and Richardson, L. R. (1951). Folic Acid Content of Foods. Agriculture Handbook, No. 29. Washington.

Turchetti, L. C., Combrink, B., Krawitz, S., and Metz, J. (1966). Amer. 7. clin. Nutr., 18, 249 .

Varadi, S., Abbott, D., and Elwis, A. (1966). \%. clin. Path., 19, 33. Willoughby, M. L. N.' (1967). Brit. F. Haemat., 13, 503.

\title{
Normal Dietary Folate, Iron, and Protein Intake, with Particular Reference to Pregnancy
}

\author{
I. CHANARIN,* M.D., B.SC., D.C.P., M.C.PATH. ; DOREEN ROTHMAN, $\dagger$ B.SC., M.R.C.O.G. \\ JANET PERRY, $\ddagger$ B.SC. ; D. STRATFULL,§ F.I.M.L.T.
}

Brit. med. F., 1968, 2, 394-397

Estimates for the folate content of a normal daily diet range from $53 \mu \mathrm{g}$. (Read et al., 1965), 52 to $97 \mu \mathrm{g}$. (Pace et al., 1960), $62 \mu \mathrm{g}$. (Denko et al., 1946), $47 \mu \mathrm{g}$. for a poor diet, $157 \mu \mathrm{g}$. for a low-cost diet, and $193 \mu \mathrm{g}$. for a high-cost diet (Mangay Chung et al., 1961), $101 \mu \mathrm{g}$. for elderly patients in hospitals, $145 \mu \mathrm{g}$. for the elderly at home, and $223 \mu \mathrm{g}$. for young controls (Hurdle, 1967), $157 \mu \mathrm{g}$. as "free" folate and $689 \mu \mathrm{g}$. as total folate (Butterworth et al., 1963), $400 \mu \mathrm{g}$. (Jukes, 1961), $380 \mu \mathrm{g}$. for a rural and $650 \mu \mathrm{g}$. for an urban diet (Santini

* Reader in Haematology, St. Mary's Hospital Medical School, London W.2.

t Lecturer in Obstetrics, St. Mary's Hospital Medical School, London W.2.

$¥$ Technical Officer, M.R.C. Experimental Haematology Research Unit, London $\mathbb{W} .2$.

$\$$ Chief Technician, Department of Obstetrics, St. Mary's Hospital, London $\mathbf{W} .2$. et al., 1962) to 1,000 to $1,500 \mu \mathrm{g}$. (Jandl and Lear, 1956). Some of these data have been compiled from food tables (generally unreliable as regards folate values); others by direct microbiological assay of food extracts with either Streptococcus faecalis or Lactobacillus casei; and, finally, some data have been derived by microbiological assay after treatment of the food with enzymes that release complex forms of folate not directly available for assay. Further, food folate is labile, being lost on storage, and over $90 \%$ of the folate may be lost during. cooking. Failure to use appropriate preservatives in preparing food samples may also have led to marked loss of folate before assay. The marked variation in the published data for food folate reflects these uncertainties in technique.

As part of a study on the folate requirements in pregnancy the dietary folate intake was determined by assay of food as 